\title{
PENGELOLAAN KEUANGAN DAN SUMBER DAYA MANUSIA PADA BUMDES BULIAN KECAMATAN KUBUTAMBAHAN
}

\author{
Komang Eni Candraningsih, Ketut Yuli Sarayanti, Putu Ririn Pratiwi, Luh Putu \\ Suryantini, I Gst Ayu Desy Juliantari, Ayu Trisna Devilaksmi \\ Jurusan Akuntansi, Universitas Pendidikan Ganesha, Singaraja, Bali, Indonesia
}

\begin{abstract}
Abstrak
Penelitian ini bertujuan untuk mengungkap bagaimana Pengendalian Sumber Daya Manusia dalam Pengelolaan BUMDes melalui Sistem Kerjasama dan Sistem Konflik serta bagaimana Pengalokasian Keuntungan pada BUMDes "GUNUNG SARI MAS" Bulian. Penelitian dilakukan dengan melalui pendekatan penelitian kualitatif dengan teknik waancara dan dokumentasi. Hasil penelitian menunjukkan bahwa secara financial, BUMDes "Gunung Sari Mas" Bulian sudah dapat memberikan manfaat kepada masyarakat, BUMDes ini telah memberikan jasa layanan simpan pinjam, dan di sisi lain sudah dapat membantu memenuhi kebutuhan sehari-hari masyarakat desa Bulian dengan adanya usaha toko yang menjual berbagai macam kebutuhan pokok. Selain itu, dalam kegiatan usaha yang dilakukan oleh BUMDes "Gunung Sari Mas" Desa Bulian Kecamatan Kubutambahan, profit dialokasikan kepada pihak-pihak tertentu dengan persentase yang sama di masing-masing tahun. Profit yang diterima adalah hasil dari persentase dikali dengan SHU yang dibagikan pada setiap akhir tahun.
\end{abstract}

Kata kunci: pengelolaan keuangan; pengelolaan sumber daya manusia; BUMDes

\section{Abstract}

This study aims to reveal how the Control of Human Resources in the Management of BUMDes through the Collaboration and Conflict Systems as well as how to Allocate Profits in the Bulian "MOUNTAIN SARI MAS" BUMDes. The study was conducted through a qualitative research approach with interview techniques and documentation. The results show that financially, BUMDes "Gunung Sari Mas" Bulian has been able to provide benefits to the community, BUMDes has provided savings and loan services, and on the other hand has been able to help meet the daily needs of the Bulian village community with a shop business that sell a variety of basic needs. In addition, in the business activities carried out by BUMDes "Gunung Sari Mas" in Bulian Village, Kubutambah District, profits are allocated to certain parties with the same percentage in each year. Profit received is the result of the percentage multiplied by the SHU distributed at the end of each year.

Keywords: financial management; human resource Management; Village-Owned Enterprise

\section{Pendahuluan}

Pengalokasian Dana Desa merupakan salah satu bentuk tanggung jawab pemerintah desa dalam sistem penganggaran. Desa sebagai salah satu unit organisasi pemerintah yang berhadapan langsung dengan masyarakat dengan masyarakat dengan segala latar belakang kepentingan dan kebutuhannya mempunyai peranan yang sangat strategis. Khususnya dalam pelaksanaan tugas di bidang pelayanan publik. Desentralisasi kewenangan kewenangan yang lebih besar disertai dengan pembiayaan dan bantuan sarana prasarana yang memadai mutlak diperlukan guna penguatan otonomi desa menuju kemandirian desa. Oleh sebab itu pemerintah pengeluaran kebijakan yaitu Alokasi Dana Desa (ADD) untuk menunjang segala sector di masyarakat, baik dalam pengalokasian dana Subak, Pengalokasian dana Suka-Duka, Pengalokasian dana Pembinaan Kesejahtraan Keluarga (PKK), dan pengalokasian dana Badan Usaha Milik Negara (BUMDES), serta pengalokasian dana lainnya dan dapat meningkatkan kesejahtraan masyarakat desa yang dapat memaksimalkan pembangunan desa.

Pengertian Alokasi Dana Desa adalah anggaran keuangan yang diberian pemerintah kepada desa, yang mana sumbernya berasal dari bagi Hasil Pajak Daerah serta dari dan perimbangan keuangan pusat dan daerah yng diterima oleh kabupaten. Sesuai dengan 
Peraturan Materi Dalam Negeri No. 37 Tahun 2007 Tentang Pedoman Pengelolaan Keuangan Desa di dalam pasal 18 menyatakan bahwa, "Alokasi Dana Desa berasal dari APBD Kabupaten/ kota yang bersumber dari Dana Perimbangan Keuangan Pusat dan Daerah yang diterima oleh Pemerintah Kabupaten / kota paling sedikit 10\% (sepulih persen).

Pengelolaan Alokasi Dana Desa harus dapat memenuhi beberapa prinsip pengelolaan sebagai berikut yaitu Setiap kegiatan yang pendanaannya diambil dari Alokasi Dana Desa harus melalui perencanaan, pelaksanaan dan evaluasi secara terbuka dengan prinsip dari, oleh, dan untuk masyarakat, Serta seluruh kegiatan dan penggunaan Alokasi Dana Desa harus dapat dipertanggungjawabkan secara administrasi, teknis, hukum. Alokasi Dana Desa harus digunakan dengan prinsip hemat, terarah, dan terkendali, jenis kegiatan yang di danai melalui Alokasi Dana Desa diharapkan mampu untuk meningkatkan sarana pelayanan masyarakat berupa pemenuhan kebutuhan dasar, pengutan kelembagaan desa dan kegiatan lainnya yang dibutuhkan masyarakat desa dengan penggambilan keputusan melalui jalan musyawarah, dan Alokasi Dana Desa harus dicatat di dalam Anggaran Pendapatan dan Belanja Desa melalui proses penganggaran yang sesuai dengan mekanisme yang berlaku.

Alokasi dana desa merupakan salah satu bentuk hubungan keuangan antar tingkat pemerintah yaitu hubungan keuangan antara pemerintah kabupaten tingkat desa. Untuk dapat merumuskan hubungan keuangan yang sesuai maka diperlukan pemahaman mengenai kewenangan yang dimiliki pemerintah desa meliputi kewenangan yang sudah ada berdasarkan hak asal usul, kewenangan lokal yang berkala desa, kewenangan yang ditugaskan pemerintah dan pemda provinsi, kabupaten atau kota menurut Undang- Undang No.6 Tahun 2014 tentang desa Artinya anggaran pemerintah yang diberikan kepada desa terkait sepenuhnya adalah untuk fasilitas pembangunan dan pemberdayaan desa sebagai salah satu lembaga yang andil dalam format kepemerintahaan.

Dana tersebut harus digunakaan dan dialokasikan sebagai mana mestinya sesuai dengan undang-undang dan ketentuan yang berlaku yang telah diterapkan pemerintah indanesia, sehinggaa Alokasi Dana Desa tersebut mampu meningkatkan pembangunan desa, paratisipasi masyarakat dalam memberdayakan dan mengimplementasikan bantuan tersebut untuk kedepan, Atas dasar masalah pengalokasian dana di Desa Bulian, Kecamatan Kubutambahan maka kami tertarik untuk mengangkat masalah tentang sistem penganggaran pada Badan Usaha Milik Desa (BUMDES) Bulian tersebut sebagai bahan penelitian.

Berdasarkan latar belakang di atas, maka adapun masalah yang dapat dirumuskan yaitu, bagaimana Pengendalian Sumber Daya Manusia dalam Pengelolaan BUMDes melalui Sistem Kerjasama dan Sistem Konflik serta bagaimana Pengalokasian Keuntungan pada BUMDes "GUNUNG SARI MAS" Bulian.

\section{Hasil dan Pembahasan}

Pengelolaan anggaran desa pada Desa Bulian, Kecamatan Kubutambahan, Kabupaten Buleleng yang pada 3 (tiga) tahun terakhir mengalokasikan dana tersebut ke pengelolaan BUMDes Bulian "GUNUNG SARI MAS". Pengelolaan BUMDes harus dikelola secara professional dan mandiri sehingga diperlukan orang-orang yang memiliki kompetensi untuk memngelolanya. Pemilihan pegawai ataupun manajer dan selevel harus disesuaikan dengan standar yang sudah ditetapkan dalam AD/ART BUMDes. Contohnya bagi pemegang jabatan manajer setidaknya memiliki pengalaman kerja di lembaga yang bertujuan mencari keuntungan. Latar belakang pendidikan sekurang-kurangnya SMU atau sederajat. Bagi pemegang jabatan bagian keuangan, bendahara,sekertaris diutamakan berasal dari sekolah kejuruan(SMK/SMEA) atau Diploma III bidang akuntansi atau sekretaris.

Latar belakang pendidikan bagi pemegang jabatan ini penting agar dapat menjalankan peran dan fungsinya sesuai dengan tuntutan pekerjaan. Sedangkan karyawan diutamakan memiliki latar belakang pendidikan minimal SMP. Ini menyebabkan mereka harus mampu menyusun laporan aktivitas BUMDes yang berkaitan dengan pekerjaannya. Seperti contoh karyawan di Unit Jasa Perdagangan, mereka harus menyusun laporan barang-barang terjual dan sisa barang di toko atau di gudang setiap periode tertentu ( 3 bulan atau 6 bulan sekali). 
Sebagai panduan kerja perlu disusun adanya job desk/deskripsi tanggung jawab dan wewenang pada masing-masing lini organisasi.

Sebagai sebuah lembaga yang juga diwajibkan mendapat profit, tentunya ada mekanisme yang harus ditaati oleh pengelola BUMDes dalam melakukan kerja sama dengan pihak lain. Misalnya kegiatan yang bersifat lintas desa perlu dilakukan koordinasi dan kerjasama antar pemerintah desa dalam pemanfaatan sumber-sumber ekonomi, misalnya sumber air bagi air minum, dan lain-lain. Dalam melakukan kerja sama dengan pihak ketiga, pengelola harus berkonsultasi dan mendapat persetujuan dari pengurus BUMDes. Dalam kegiatan harian pengelola harus mengacu pada tata aturan yang sudah disepakati bersama sebagaimana yang telah tertuang dalam AD/ART BUMDes serta sesuai prinsip-prinsip tata kelola BUMDes.

Satu hal yang penting dalam pengelolaan BUMDes yaitu dalam proses pengelolaan BUMDes amat dibutuhkan suatu pengelolaan dan pelaporan yang transparan bagi pemerintah dan masyarakat. Artinya dasar pengelolaan harus serba transparan dan terbuka sehingga ada mekanisme check and balance baik dari pemerintah desa maupun masyarakat. Untuk langkah ke depan sangat diperlukan sebuah penyusunan rencanarencana pengembangan usaha, misalkan untuk produk-produk yang dipengaruhi oleh musim seperti penjualan pakaian, sandal, sepatu dan sejenisnya penting untuk memperhatikan mode, sebab jika tidak dilakukan besar kemungkinan produknya tidak diminati di pasaran. Untuk itu perlu dilakukannya inovasi-inovasi baru atau selalu mewaspadai perubahan dan perkembangan yang terjadi di masyarakat.

Dari ulasan di atas hasil yang kami peroleh dari narasumber di BUMDes "Gunung Sari Mas" yang terdiri dari:

a. Struktur Organisasi Pada BUMDes "Gunung Sari Mas"

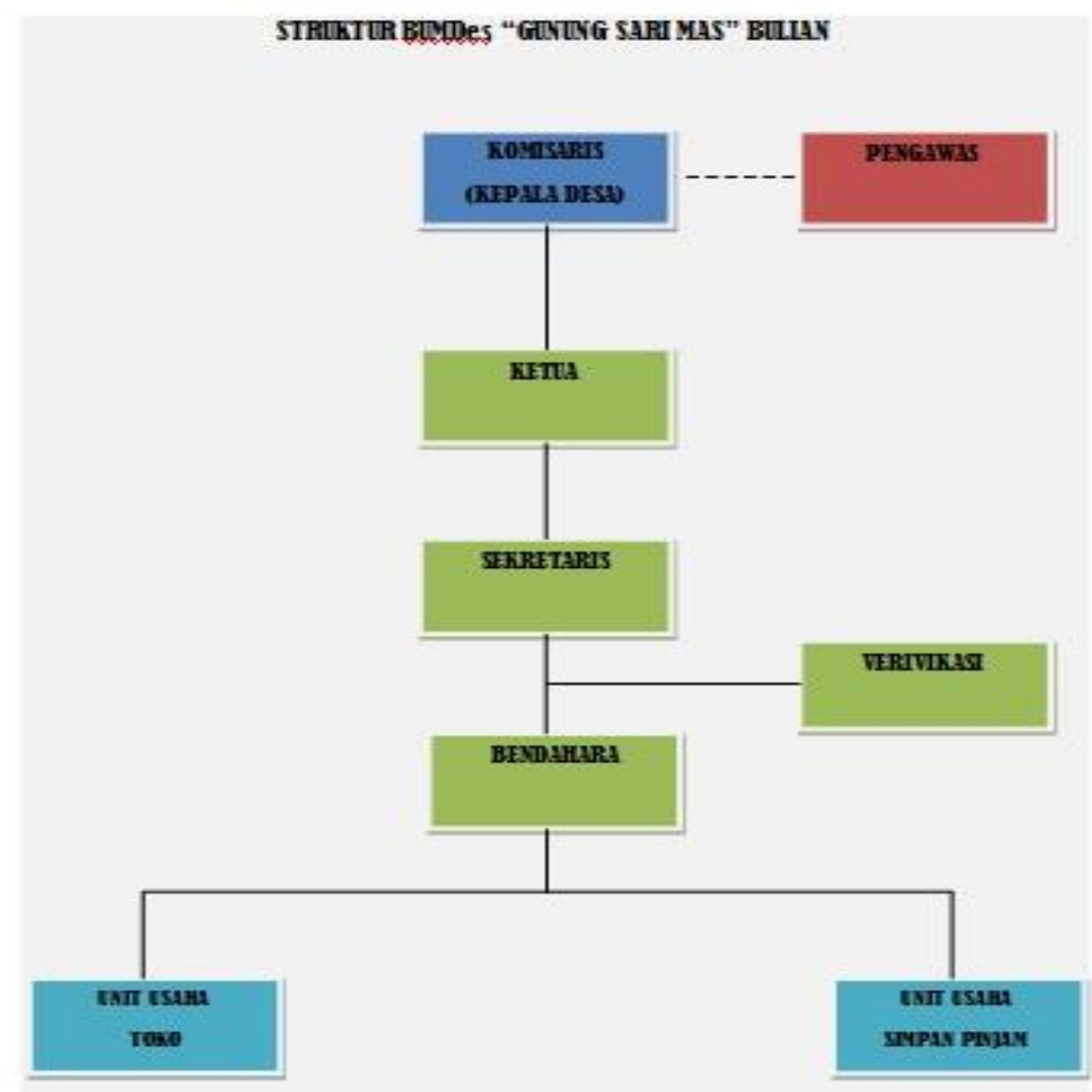

Gambar 1. Struktur Organsisasi BUMDes Bulian Kec.Kubutambahan 
b. Neraca Akhir Tahun 2016

\section{BUMDes "GUNUNG SARI MAS” BULIAN}

\begin{tabular}{|c|c|c|c|c|c|}
\hline Kode & Aktiva & Jumlah & Kode & Pasiva & Jumlah \\
\hline \multirow[t]{3}{*}{111} & Kas & & 210 & Tabungan & Rp 636.781.707 \\
\hline & $\begin{array}{l}\text { a. Unit simpan } \\
\text { pinjam }\end{array}$ & Rp 265.156.111 & 214 & Titipan & Rp 837.5000 \\
\hline & b. Unit took & $\mathrm{Rp} 21.676 .120$ & 213 & Hutang & Rp 10.000.000 \\
\hline \multirow[t]{3}{*}{114} & Pinjaman diberikan & $\begin{array}{l}\mathrm{Rp} \\
1.148 .738 .454\end{array}$ & & & \\
\hline & $\begin{array}{l}\text { Persediaan barang } \\
\text { dagangan }\end{array}$ & Rp 243.301.982 & & & \\
\hline & Total aktva lancar & $\begin{array}{l}\mathrm{Rp} \\
1.678 .872 .758\end{array}$ & 312 & Modal donasi & Rp 989.700.000 \\
\hline \multirow[t]{8}{*}{115} & Inventaris & & 316 & Cadangan modal & Rp 214.713.515 \\
\hline & $\begin{array}{l}\text { a. Unit simpan } \\
\text { pinjam }\end{array}$ & $\mathrm{Rp} 48.227 .500$ & 317 & $\begin{array}{l}\text { SHU periode Jan- } \\
\text { Des } 2014\end{array}$ & Rp 247.095.245 \\
\hline & $\begin{array}{l}\text { Akumulasi } \\
\text { penyusutan }\end{array}$ & $(\operatorname{Rp} 13.414 .436)$ & & SHU dibagikan & $\begin{array}{l}(\mathrm{Rp} \\
111.192 .860)\end{array}$ \\
\hline & b. Unit took & Rp 177.151.600 & & & \\
\hline & $\begin{array}{l}\text { Akumulasi } \\
\text { penuyusutan }\end{array}$ & $(\operatorname{Rp} 29.552 .315)$ & & & \\
\hline & c. Gedung & Rp 138.000.000 & & & \\
\hline & $\begin{array}{l}\text { Akumulasi } \\
\text { penyusutan }\end{array}$ & $(\operatorname{Rp} 23.000 .000)$ & & & \\
\hline & Total Aktiva tetap & Rp 297.412.349 & & & \\
\hline \multirow[t]{2}{*}{117} & Aktiva lain-lain & Rp 1.650.000 & & & \\
\hline & Total aktiva & $\begin{array}{l}\text { Rp } \\
1.977 .935 .107\end{array}$ & & Total Pasiva & $\begin{array}{l}\text { Rp } \\
1.977 .935 .107\end{array}$ \\
\hline
\end{tabular}

\subsection{Pengendalian Sumber Daya Manusia Dalam Pengelolaan BUMDes Melalui Sistem Kerjasama Dan Sistem Konflik.}

Berkaitan dengan sumber daya manusia yang berkualitas akan membantu pertumbuhan perekonomian desa melalui pengalokasian SDM yang benar dan tepat. Dalam hal ini dikaitkan dengan kegiatan pelaksanaan BUMDes. Badan Usaha Milik Desa (BUMDes) merupakan lembaga usaha desa yang dikelola oleh masyarakat dan pemerintah desa dalam upaya memperkuat perekonomian desa dan dibentuk berdasarkan kebutuhan dan potensi desa. Adapun pengertian BUMDes lainnya yaitu :

1. BUMDes menurut Undang-undang Nomor 32 Tahun 2004 tentang Pemerintah Daerah didirikan antara lain dalam rangka peningkatan Pendapatan Asli Desa (PADesa).

2. BUMDes menurut Maryunani (2008) "BUMDes merupakan lembaga usaha desa yang dikelola oleh masyarakat dan pemerintahan desa dalam upaya memperkuat perekonomian desa dan membangun kerekatan social masyarakat yang dibentuk berdasarkan kebutuhan dan potensi desa".

3. BUMDes mnurut Peraturan Menteri Dalam Negeri Nomor 39 Tahun 2010 Tentang Badan Usaha Milik Desa yang menyatakan bahwa "BUMDes adalah badan usaha desa yang dibentuk atau didirikan oleh pemerintah desa yang kepemilikan modal dan pengelolaannya dilakukan oleh pemerintah desa dan masyarakat". 
4. Menurut Pusat Kajian Dinamika Sistem Pembangunan (2007) menyatakan "Badan Usaha Milik Desa (BUMDes) merupakan lembaga usaha desa yang dikelola oleh ,asyarakat dan pemerintah desa dalam upaya memperkuat perekonomian desa dan dibentuk berdasarkan kebutuhan dan potensi desa".

Dalam mendirikan Badan Usana Milik Desa (BUMDes) tentunya memiliki tujuan untuk membantu kesejahteraan dan perekonomian bagi Desa. Adapun empat tujuan utama didirikannya BUMDes adalah sebagai berikut :

1) Meningkatkan perekonomian desa.

2) Meningkatkan pengelolaan ptensi desa sesuai dengan kebutuhan masyarakat.

3) Menjadi tulang punggung pertumbuhan dan pemerataan ekonomi desa.

4) Meningkatkan pendapatan asli desa.

Pendirian dan pengelolaan Badan Usaha Milik Desa (BUMDes) merupakan wujud dari pengelokaan ekonomi produktif desa yang dilaksanakan secara kooperatif, partisipatif, akuntabel, transparansi, serta sustaniabel. Maka dari itu, sangat diperlukan upaya yang serius untuk menjadikan pengelolaan BUMDes dapat berjalan secara mandiri, efisien, efektif serta professional.

Untuk mencapai tujuan dari BUMNDes seperti yang dipaparkan di atas, maka harus dilakukan dengan cara memenuhi kebutuhan (konsumtif dan produktif) masyarakat melalui pelayanan barang dan jasa yang dikelola oleh masyarakat serta pemerintah desa.

BUMDes diharapkan serta dituntut agar mampu memberikan pelayanan kepada pihak luar desa dengan menempatkan harga serta pelayanan yang sesuai dengan standar pasar yang berarti terdapat mekanisme kelembagaan yang disepakati bersama sehingga tidak menimbulkan disorsi ekonomi pedesaan yang disebablan oleh usaha BUMDes.

Sesuai yang dinyatakan dalam Undang-undang bahwa BUMDes dapat didirikan sesuai dengan kebutuhan dan potensi desa. Kebutuhan dan potensi desa adalah kebutuhan masyarakat terutama dalam pemenuhan kebutuhan pokok, tersedianya sumber daya desa yang belum dimanfaatkan secara optimal terutama kekayaan desa dan terdapat permintaan di pasar. Tersedianya sumber daya manusia yang mampu mengelola badan usaha sebagai asset penggerak perekonomian masyarakat.

Menurut Nawawi (2001) ada tiga pengertian sumber daya manusia yaitu :

1) Sumber daya manusia adalah manusia yang bekerja di lingkungan suatu organisasi (disebut juga personil, tenagakerja, pekerja, atau karyawan).

2) Sumber daya manusia adalah potensi manusiawi sebagai penggerak organisasi dalam mewujudkan eksistensinya.

3) Sumber daya manusia adalah potensi yang merupakan aset dan berfungsi sebagai modal (non material atau non financial) di dalam organisasi bisnis, yang dapat mewujudkan menjadi potensi nyata (real) secara fisik dan non fisik dalam mewujudkan eksistensi organisasi.

Adanya unit-unit usaha yang merupakan kegiatan ekonomi warga masyarakat yang dikelola secara parsial dan kurang terakomodasi. BUMDes merupakan wadah untuk menjalankan usaha di desa. Jenis usaha yang dimaksud meliputi pelayanan ekonomi desa yang terdiri dari usaha jasa keuangan, penyaluran bahan pokok ekonomi desa, perdagangan hasil pertanian, serta industri dan kerajinan masyarakat.

Pemerintah desa sebagai penyerta modal BUMDes atau sebagai pendiri bersama masyarakat diharapkan dapat memenuhi standar pelayanan miniman (SPM) yang diwujudkan dalam bentuk perlindungan atas intervensi yang merugikan dari pihak ketiga baik dari dalam maupun luar desa. Pemerintah desa juga harus ikut serta dalam pembentukan BUMDes yang selalu mengacu pada peraturan perundangan yang berlaku serta sesuai dengan kesepakatan yang dibangun oleh seluruh lapisan masyarakat desa.

BUMDes "Gunung Sari Mas" merupakan badan usaha milik desa (BUMDes) Desa Bulian, Kecamatan Kubutambahan yang berdiri pada bulan Februari tahun 2013 dengan unit usaha simpan pinjam dan usaha toko yang mana modal awal berasal dari Gerbang Sadu Mandara. Secara financial, BUMDes "Gunung Sari Mas" Bulian sudah dapat memberikan manfaat kepada masyarakat, BUMDes ini telah memberikan jasa layanan simpan pinjam, dan di sisi lain sudah dapat membantu memenuhi kebutuhan sehari-hari masyarakat desa 
Bulian dengan adanya usaha toko yang menjual berbagai macam kebutuhan pokok. Kepala BUMDes Bulian saat diwawancarai juga mengatakan bahwa seluruh lapisan masyarakat sudah dapat merasakan manfaat dari pendirian BUMDes tersebut. BUMDes juga sangat bermanfaat karena seluruh karyawan BUMDes "Gunung Sari Mas" Bulian adalah masyarakat asli Desa Bulian.

Dari awal berdirinya BUMDes "Gunung Sari Mas" Bulian hingga saat ini masih beroprasi dengan baik dan selalu mengalami peningkatan selama tiga tahun terakhir, akan tetapi seiring dengan peningkatan yang dicapai oleh BUMDes "Gunung Sari Mas" Bulian tentu saja ada beberapa masalah yang dialami oleh BUMDes "Gunung Sari Mas" Bulian salah satunya yaitu sering terjadi kehilangan persediaan barang dagangannya yang ada di toko padahal di toko tersebut sudah dipasang kamera CCTV yang banyaknya ada enam dan dipasang di setiap sudut toko dan di kasir. Menurut ketua BUMDes "Gunung Sari Mas" Bulian hal tersebut disebabkan oleh kurangnya pengendalian internal dalam toko tersebut dan hal itu tidak lepas dari manajemen sumber daya manusia yang diterapkan di BUMDes "Gunung Sari Mas" Bulian.

Dalam memanajemen sumber daya manusia di BUMDes "Gunung Sari Mas" Bulian, ketua BUMDes "Gunung Sari Mas" Bulian berserta jajarannya menggunakan sistem pengendalian sumber daya manusia (pegawai toko) dengan sistem kerjasama. Sistem kerjasama merupakan sistem dimana seluruh pegawai toko dalam melaksanakan tugasnya harus saling bekerjasama dalam menangani masalah kehilangan persediaan barang dagangan yang sering terjadi di toko tersebut. Jadi, ketika terjadi kehilangan persediaan barang dagangan dimana, persediaan yang ada di sistem komputer tidak sesuai dengan persediaan yang ada di toko.

Maka, kerugiaan atas kehilangan persediaan barang ditoko akan ditanggung oleh seluruh pegawai toko tersebut secara merata dengan memotong gaji pegawai toko diakhir bulan. Namun, sistem pengendalian sumber daya manusia dengan kerjasama dianggap tidak efektif karena pegawai toko yang jujur ikut menanggung kerugian atas kehilangan persediaan barang dagangan, sehingga banyak pegawai toko yang berhenti bekerja karena mereka merasa dirugikan. Untuk mengatasi hal tersebut maka ketua BUMDes "Gunung Sari Mas" Bulian beserta jajarannya mengubah sistem pengendalian sumber daya manusia dengan kerjasama menjadi sistem pengendalian sumber daya manusia dengan konflik. Sistem pengendalian sumber daya manusia dengan konflik merupakan suatu sistem yang dimana seluruh pegawai toko dituntut untuk saling mencurigai antar satu pegawai dengan pegawai lainnya.

Jadi maksudnya ketika ada pegawai toko yang terindikasi melakukan suatu kecurangan maka, pegawai yang lainnya harus melaporkannya kepada ketua BUMDes. Jika yang dikatakan oleh pegawai tersebut memang benar maka, pegawai tersebut akan diberikan fee atas keberanian pegawai tersebut melaporkan kecurangan yang telah dilakukan oleh salah satu pegawai toko tersebut. Hingga saat ini, sistem pengendalian sumber daya manusia dengan konflik masih efektif digunakan karena masalah kehilangan persediaan barang dagangan yang biasanya sering terjadi kini sudah mengalami penurunan. Dan hal tersebut menyebabkan semua pegawai toko yang ingin melakukan suatu kecurangan akan berpikir duakali untuk melakukannya karena mereka merasa takut apabila perbuatan tersebut dilaporkan oleh salah satu pegawai yang mengetahuinya.

\subsection{Pengalokasian Profit BUMDes Bulian Tahun 2014-2016}

Pengalokasian dapat diartikan sebagai pembagian, penjatahan, atau pendistribusian. Sedangkan profit merupakan selisih antara pendapatan yang dikurangi dengan pengeluaran. Jika pendapatan lebih besar daripada pengeluaran maka bisnis yang sedang dijalankan dapat dikatakan untung, sebaliknya jika pengeluaran lebih besar daripada pendapatan maka bisnis tersebut dikatakan rugi. Profit juga dapat dikatakan sebagai keuntungan. Setiap kegiatan usaha atau bisnis di dalam memperoleh profit pasti akan mengalokasikan profit tersebut dengan beberapa pertimbangan. Biasanya, profit akan dialokasikan ke pihak-pihak tertentu yang berkaitan dengan kegiatan usaha atau bisnis tersebut. 
Dalam hal ini, BUMDes "Gunung Sari Mas" yang terdapat pada Desa Bulian Kecamatan Kubutambahan yang berdiri pada bulan Februari tahun 2013 menjalankan kegiatan usaha simpan pinjam dan usaha toko yang mana modal awalnya berasal dari Gerbang Sadu Mandara. Sama halnya seperti kegiatan usaha atau bisnis lainnya, BUMDes yang menjalankan usaha dalam bentuk usaha toko ini mengalokasikan profit atas usaha tersebut ke beberapa pihak. Pengalokasian profit atas kegiatan usaha ini dilaksanakan di setiap akhir tahun. Pada pembahasan ini akan dipaparkan mengenai pengalokasian profit BUMDes "Gunung Sari Mas" dari tahun 2014-2016.

Persentase untuk pengalokasian profit ke beberapa pihak dari tahun 2014-2016 adalah sama, persentase tersebut adalah sebagai berikut :

1. $55 \%$ dari Sisa Hasil Usaha (SHU) yang dibagikan untuk cadangan modal.

2. $20 \%$ dari SHU yang dibagikan untuk PAD Desa

3. $10 \%$ dari SHU yang dibagikan untuk pengurus desa.

4. $10 \%$ dari SHU yang dibagikan untuk pengurus BUMDes.

5. $5 \%$ dari SHU yang dibagikan untuk dana sosial dan pelatihan.

Di tahun 2014, pengalokasian profit adalah sebagai berikut :

1. $55 \%$ dari Sisa Hasil Usaha (SHU) yang dibagikan untuk cadangan modal.

Cadangan modal = Persentase $\times$ SHU yang dibagikan

$=55 \% \times R p 72.310 .865$

$=\operatorname{Rp} 39.770 .975,75$

2. $20 \%$ dari SHU yang dibagikan untuk PAD Desa

PAD Desa = Persentase $\times$ SHU yang dibagikan

$=20 \% \times R p 72.310 .865$

$=\operatorname{Rp} 14.462 .173$

3. $10 \%$ dari SHU yang dibagikan untuk pengurus desa.

Pengurus desa

$=$ Persentase $\times$ SHU yang dibagikan

$=10 \% \times \operatorname{Rp} 72.310 .865$

$=\operatorname{Rp} 7.231 .086,5$

4. $10 \%$ dari SHU yang dibagikan untuk pengurus BUMDes.

Pengurus BUMDes = Persentase $\times$ SHU yang dibagikan

$=10 \% \times R p 72.310 .865$

$=\operatorname{Rp} 7.231 .086,5$

5. $5 \%$ dari SHU yang dibagikan untuk dana sosial dan pelatihan.

Dana sosial dan pelatihan $=$ Persentase $\times$ SHU yang dibagikan

$=5 \% \times R p 72.310 .865$

$=\operatorname{Rp} 3.615 .543,25$

Di tahun 2015, pengalokasian profit adalah sebagai berikut:

1. $55 \%$ dari Sisa Hasil Usaha (SHU) yang dibagikan untuk cadangan modal.

Cadangan modal

$=$ Persentase $\times$ SHU yang dibagikan

$=55 \% \times R p 92.322 .511$

$=\operatorname{Rp} 50.777 .381,05$

2. $20 \%$ dari SHU yang dibagikan untuk PAD Desa

PAD Desa = Persentase $\times$ SHU yang dibagikan

$=20 \% \times 92.322 .511$

$=18.464 .502,2$

3. $10 \%$ dari SHU yang dibagikan untuk pengurus desa.

Pengurus desa

$=$ Persentase $\times$ SHU yang dibagikan

$=10 \% \times R p 92.322 .511$

$=R p$ 9.232.251,1

4. $10 \%$ dari SHU yang dibagikan untuk pengurus BUMDes.

Pengurus BUMDes = Persentase $\times$ SHU yang dibagikan

$=10 \% \times R p 92.322 .511$ 


$$
=\operatorname{Rp} 9.232 .251,1
$$

5. 5\% dari SHU yang dibagikan untuk dana sosial dan pelatihan.

Dana sosial dan pelatihan $=$ Persentase $\times$ SHU yang dibagikan

$$
\begin{aligned}
& =5 \% \times R p 92.322 .511 \\
& =\operatorname{Rp~4.616.125,55~}
\end{aligned}
$$

Di tahun 2016, pengalokasian profit adalah sebagai berikut :

1. $55 \%$ dari Sisa Hasil Usaha (SHU) yang dibagikan untuk cadangan modal.

$$
\begin{aligned}
\text { Cadangan modal } & =\text { Persentase } \times \text { SHU yang dibagikan } \\
& =55 \% \times R p 11.192 .860 \\
& =\mathrm{Rp} 6.156 .073
\end{aligned}
$$

2. $20 \%$ dari SHU yang dibagikan untuk PAD Desa

$$
\begin{aligned}
\text { PAD Desa } & =\text { Persentase } \times \text { SHU yang dibagikan } \\
& =20 \% \times R p 11.192 .860 \\
& =\mathrm{Rp} 2.238 .572
\end{aligned}
$$

3. $10 \%$ dari SHU yang dibagikan untuk pengurus desa.

$$
\begin{aligned}
\text { Pengurus desa } & =\text { Persentase } \times \text { SHU yang dibagikan } \\
& =10 \% \times R p 11.192 .860 \\
& =R p 1.119 .286
\end{aligned}
$$

4. $10 \%$ dari SHU yang dibagikan untuk pengurus BUMDes.

$$
\begin{aligned}
\text { Pengurus BUMDes } & =\text { Persentase } \times \text { SHU yang dibagikan } \\
& =10 \% \times R p 11.192 .860 \\
& =\mathrm{Rp} 1.119 .286
\end{aligned}
$$

5. 5\% dari SHU yang dibagikan untuk dana sosial dan pelatihan.

$$
\begin{aligned}
\text { Dana sosial dan pelatihan } & =\text { Persentase } \times \text { SHU yang dibagikan } \\
& =5 \% \times R p 11.192 .860 \\
& =R p 559.643
\end{aligned}
$$

Pengalokasian profit untuk masing-masing tahun akan dikelola lagi oleh pihak-pihak yang menerima. Misalnya, untuk pengurus BUMDes nantinya akan mengalokasikan lagi profit yang diterima ke pihak-pihak terkait. Misalnya di tahun 2014, pengurus BUMDes mendapat pembagian profit sebesar Rp 7.231.086,5 dimana nantinya profit tersebut akan dialokasikan lagi (dibagikan) kepada seluruh pengurus BUMDes tanpa terkecuali serta akan diberikan juga kepada pegawai toko dalam bentuk bonus akhir tahun, maka setiap akhir tahun saat pembagian profit, bukan hanya pihak-pihak tertentu saja yang menerima hasil atau profit atas usaha toko tersebut, pegawai toko pun dapat merasakan profit atau keuntungan yang diperoleh.

\section{Simpulan dan Saran}

Kesimpulan yang dapat diambil dari pengelolaan keuangan dan sumber daya manusia pada bumdes bulian kecamatan kubutambahan, yaitu:

1. BUMDes menurut Undang-undang Nomor 32 Tahun 2004 tentang Pemerintah Daerah didirikan antara lain dalam rangka peningkatan Pendapatan Asli Desa (PADesa).

BUMDes diharapkan serta dituntut agar mampu memberikan pelayanan kepada pihak luar desa dengan menempatkan harga serta pelayanan yang sesuai dengan standar pasar yang berarti terdapat mekanisme kelembagaan yang disepakati bersama sehingga tidak menimbulkan disorsi ekonomi pedesaan yang disebabkan oleh usaha BUMDes. BUMDes "Gunung Sari Mas" merupakan badan usaha milik desa (BUMDes) Desa Bulian, Kecamatan Kubutambahan yang berdiri pada bulan Februari tahun 2013 dengan unit usaha simpan pinjam dan usaha toko yang mana modal awal berasal dari Gerbang Sadu Mandara. Secara financial, BUMDes "Gunung Sari Mas" Bulian sudah dapat memberikan manfaat kepada masyarakat, BUMDes ini telah memberikan jasa layanan simpan pinjam, dan di sisi lain sudah dapat membantu memenuhi kebutuhan sehari-hari masyarakat desa Bulian dengan adanya usaha toko yang menjual berbagai macam kebutuhan pokok. Dari awal berdirinya BUMDes "Gunung Sari Mas" Bulian hingga saat ini masih beroprasi 
dengan baik dan selalu mengalami peningkatan selama tiga tahun terakhir, akan tetapi seiring dengan peningkatan yang dicapai oleh BUMDes "Gunung Sari Mas" Bulian tentu saja ada beberapa masalah yang dialami oleh BUMDes "Gunung Sari Mas" Bulian salah satunya yaitu sering terjadi kehilangan persediaan barang dagangannya yang ada di toko padahal di toko tersebut sudah dipasang kamera cctv yang banyaknya ada enam dan dipasang di setiap sudut toko dan di kasir. Maka untuk mengatasi hal tersebut maka ketua BUMDes "Gunung Sari Mas" Bulian menggunakan sistem pengendalian sumber daya manusia dengan kerjasama, kemudian diganti dengan sistem pengendalian sumber daya manusia dengan konflik karena dianggap lebih efektif dari sistem yang sebelumnya.

2. Pengalokasian dapat diartikan sebagai pembagian, penjatahan, atau pendistribusian. Sedangkan profit merupakan selisih antara pendapatan yang dikurangi dengan pengeluaran. Jika pendapatan lebih besar daripada pengeluaran maka bisnis yang sedang dijalankan dapat dikatakan untung, sebaliknya jika pengeluaran lebih besar daripada pendapatan maka bisnis tersebut dikatakan rugi. Jadi pengalokasian profit merupakan pembagian, penjatahan, atau pendistribusian profit atau keuntungan ke berbagai pihak terkait dalam suatu kegiatan usaha atau bisnis. Profit biasanya dialokasikan pada akhir tahun atau akhir periode. Pihak penerima profit juga dapat mengalokasikan profit tersebut kepada pihak-pihak yang dikehendaki. Dalam kegiatan usaha yang dilakukan oleh BUMDes "Gunung Sari Mas" Desa Bulian Kecamatan Kubutambahan, profit dialokasikan kepada pihak-pihak tertentu dengan persentase yang sama di masing-masing tahun. Profit yang diterima adalah hasil dari persentase dikali dengan SHU yang dibagikan pada setiap akhir tahun.

Adapun saran yang dapat kami sampaikan dalam penulisan makalah ini adalah sebagai berikut:

a. Bagi penulis, penulis hendaknya memiliki refrensi dan data yang lebih lengkap agar penulisan hasil penelitian dapat diandalkan dan akurat untuk dijadikan pedoman penulisan selanjutnya. Hal tersebut dapat terjadi disebabkan kurangnya waktu untuk melakukan wawancara dengan narasumber yang memiliki jadwal yang padat, maka dari itu penulis diharapkan dapat lebih selektif dan aktif dalam mengatas hal tersebut.

b. Bagi pembaca/masyarakat, diharapkan dapat memahami betul mengenai sistem pengelolaan keuangan dalam organisasi BUMDes Bulian yang nantinya dapat diterapkan untuk kegiatan yang terkait dalam pengelolaan keuangan.

c. Bagi pemerintah, pemerintah diharapkan dapat berpartisipasi lebih dalam pembangunan desa melalui pengalokasian dana desa secara rutin dan tanpa hambatan yang berarti, serta membuat program maupun kebijakan-kebijakan yang efektif dalam meningkatkan kinerja lembaga desa dan masyarakat desa di Indonesia demi kemajuan bangsa.

\section{DAFTAR PUSTAKA}

Sauqi,Mubarok."BadanUsahaMilikDesaBUMDes"http://wongsorejoku.blogspot.co.id/2013/10/ badan-usaha-milik-desa-bumdes-apa.html (diakses tanggal 29 Desember 2016)

Prayudi, Aristia Made dan Komang Adi Kurniawan Saputra. 2016. Akuntansi Pemerintahan. Singaraja: Istiqlal 